\title{
Total Quality Management Practices on Employees' Job Involvement in Nepalese Manufacturing Industry
}

\author{
Bhupindra Jung Basnet \\ Lecturer, Nepal Commerce Campus
}

\begin{abstract}
The purpose of this paper is to examine the impact of total quality management practices on employees' job involvement in Nepalese manufacturing industry. Structural questionnaire are used. Data was analyzed by employing correlation and sample regression analysis. The result of this study revealed that customer focus, training and education, teamwork, and organizational culture are positively associated with employees' job involvement. This study contributes for advancing the TQM research literature to a better understanding of the association between TQM practices and employees' job involvement within Nepalese manufacturing industry.
\end{abstract}

Keywords- Total quality management practices, Employees' job involvement, Nepalese manufacturing industry

\section{Introduction}

Total quality management (TQM) is a holistic management philosophy focusing on the maintenance and continuous improvement of products, services, people, and processes at all levels and in all functions of the organization with the goal to meet or exceed customer expectations (Goetsch and Davis, 1994). TQM is an organization-wise approach to continuously improve the quality of the organization, processes, products and services (Thapa, 2067).

TQM has a people-oriented approach and incorporates many aspects of organizational behavior (Luthans, 1995). Guimaraes (1996) identified several indicators for work- related attitudes. These included task characteristics, job involvement, job satisfaction, career satisfaction, and organizational commitment. Principles of Management by Quality deals with the human oriented approach and mindset for quality, and relates with implementation of total quality management (Chapagain, 2010).

The Nepal Standard (NS) award is each year given to the manufacturing industry, which has been producing consistent quality products over the years. The Federation of Nepalese Chambers of Commerce and Industry (FNCCI) National Excellence Award is awarded to the industry which is the best business performance excellence (Chapagain, 2010). TQM itself is a technique for employee involvement. Unless all employees take responsibility for quality management, it is not possible to implement properly (Adhikari, 2008). In theory, TQM is empowering employees to be more involved in their jobs and to participate in TQM decision- making activities. TQM 
practices enhance job involvement among employees (Karia and Asaari, 2006).

Different studies showed that TQM practices impact on employees' job involvement (Guimaraes, 1996; Karia and Asaari, 2006; Ooi, Arumugam, Safa and Bakar, 2007a). In Nepalese context, TQM practices and employees' job involvement have nominal literatures. Thus, this study adds new literature in the field of TQM practices and employees' job involvement in Nepalese manufacturing industry.

\section{Review of literature}

TQM focuses not only on the quality of product, but also on the quality of employees. Most successful TQM implementations depend heavily on changes in employees' attitudes and activities (Karia and Asaari, 2006). A number of Nepalese entrepreneurs, professionals, academicians, some supervisors and work leaders have developed awareness about productivity, quality management system and total quality management (Chapagain, 2002).

In this paper, TQM practices are customer focus, training and education, teamwork, and organizational culture (Ooi, et al, 2005; Karia and Asaari, 2006). Employees' work-related attitude is employees' job involvement (Guimaraes, 1996). TQM practices impact on employees' job involvement (Karia and Asaari, 2006; Ooi, et al., 2007a; Batista, et al., 2013). Job involvement can also be defined as an individual's ego involvement with work (Kanungo, 1982). Ooi, et al., (2007b) and Zhang, (2000) argued that customer focus as TQM practice can be described as the degree to which organizations continuously fulfill the customer needs and expectations to enhance their performance. Customer focus was positively associated with employees' job involvement (Ooi, et al., 2005; Ooi, et al., 2007a). But customer focus was not contribution to employees' job involvement (Karia and Asaari, 2006; Batista, et al., 2013).

Talib, Rahman and Qureshi (2013) defined that training and education spread the knowledge of continuous improvement and innovation in service process to attain full benefits and business excellence. Training and education was positively relation with employees' job involvement (Ooi, et al., 2005; Karia and Asaari, 2006). However, training and education did not demonstrate any favorable contribution to the employees' job involvement (Ooi, et al., 2007a; Batista, et al., 2013).

Teamwork is defined by Ooi et al. (2007b) it refers to an increase in employees' control over their work and allows them to work as a group. Teamwork was positively related to employees' job involvement (Ooi, et al., 2005; Karia and Asaari, 2006; Ooi, et al., 2007a; Batista, et al., 2013). Hemmelgarn et al. (2001) definition was that organizational culture has been defined as the norms, values, and basic assumptions of given organization. Organizational culture was relationship with employees' job involvement (Ooi, et al., 2005).

This paper seeks to have insights into the implementation of the TQM practices from the human resource perspective. Most of the studies show high involvement of employees in TQM decision making, employees helps to improve the quality of the product. In Nepal, Thapa (2011) highlighted the needs of TQM to improve overall quality of education in Nepal. Thapa (2015) identified that management commitment, customer focus, continuous improvement, training and developments, and feedback and effective communication had positive relation with organizational performance in Nepalese tourism industry. In the context of Nepal, there is limited literature of TQM 


\section{Pravaha Journal-2018}

practices effect on employees' job involvement. Thus, the key issue of this study is whether TQM practices have significant impact on employees' job involvement or not in Nepalese manufacturing industry. The research question is that what is the impact of TQM practices explained by customer focus, training and education, teamwork, and organizational culture on employees' job involvement?

\section{TQM Practices}

TQM practices are customer focus, training and education, teamwork, and organizational culture. Customer focus is defined as the extent to which an organization continuously satisfies customer needs and expectations (Zhang, 2000). Customer focus is vital that leaders encourage the understanding of customer needs, build relationships with customers and fulfill their demands (Cai, 2009). Customer focus has been realized that the ultimate measure of an organization's performance is customer satisfaction which may very well predict the future success or failure of an organization (Kanji and Asher, 1993).

Cherrington (1995) argued that a successful training and education program would create more-favourable employee attitudes and loyalty, and help employees in their personal development and advancement. Training refers to the acquisition of specific skills or knowledge. Training programs attempt to teach employees how to perform particular activities or a specific job. Education attempts to provide employees with general knowledge that can be applied in many different settings (Cherrington, 1995).

Teamwork is a work arrangement that arguably has the capacity to enable cooperation and effective individual involvement and it represents a way of working (Gallear and Ghobadian, 2004). Teamwork includes identifying the needs of all groups and organizations involved in decision making, trying to find solutions that will benefit everyone involved, and sharing responsibility and credit (Ciampa, 1991).

Organizational culture was first used in the management literature by Pettigrew (1979) in the Administrative Science Quarterly journal. Organizational culture is a continuum or scale that is stretching from a point of invisibility and depth to a point of visibility and shallow surface. Organizational culture commonly focuses on two major aspects of culture. They are content and strength culture. Content culture signifies the types of values and behaviors held by members of a firm. Strength culture are the depth and breadth of those behaviors embedded among the members (Kotter and Heskett, 1992).

\section{Employees' job involvement}

Employees' job involvement is the employees' work- related attitude (Guimaraes, 1996). Campbell (1963) argued that attitudes are learned as a result of experiences with a particular target. Fishbein (1967) renowned that attitudes derive from one's beliefs about attitude objects. The employee attitudes of an individual were defined by the individual's affective reactions to both objective and experienced characteristics of the work organization (Igbaria, Parasuraman and Badawy, 1994).

Job involvement is defined as the creation of a strong relationship between the worker and his/her job, and the readiness to invest personal resources in the current job (Kanungo, 1982). Job involvement has been described as an attitudinal variable 
that depends on sensitivity to the work environment and an individual's personality traits (Schein, 1983). Job involvement is the degree to which a person is identified psychologically with his work or the importance of work in his total self image (Lodahl and Kejner, 1965). The objective of this paper is to examine the impact of TQM practices explained by customer focus, training and education, teamwork, and organizational culture on employees' job involvement.

\section{Research Hypotheses}

In the opinion of Guimaraes (1996), the introduction of TQM programs in the organizations positively influence the employees' job involvement. According to the review results from Ooi, et al., (2005), Soft TQM practices, mainly customer focus, education \& training, teamwork, and organizational culture, positively influences the employees' job involvement. Ooi, et al., (2007a) reported that TQM practices, particularly teamwork, and customer, was positively associated with employees' job involvement. Thus, factors of TQM practices are linked to the employees' job involvement and the research hypothesis is formed.

$H_{1}$ : Factors of TQM practices have a positive effect on employees' job involvement.

\section{Conceptual Framework}

A conceptual framework is developed to examine the effect of TQM practices on employees' job involvement. In this conceptual framework, independent variables of TQM practices are customer focus, training and education, teamwork, and organizational culture (Ooi et al., 2005; Karia and Asaari, 2006) and dependent variable is employees' job involvement (Guimaraes, 1996). (Figure I)

Figure I: Conceptual Framework

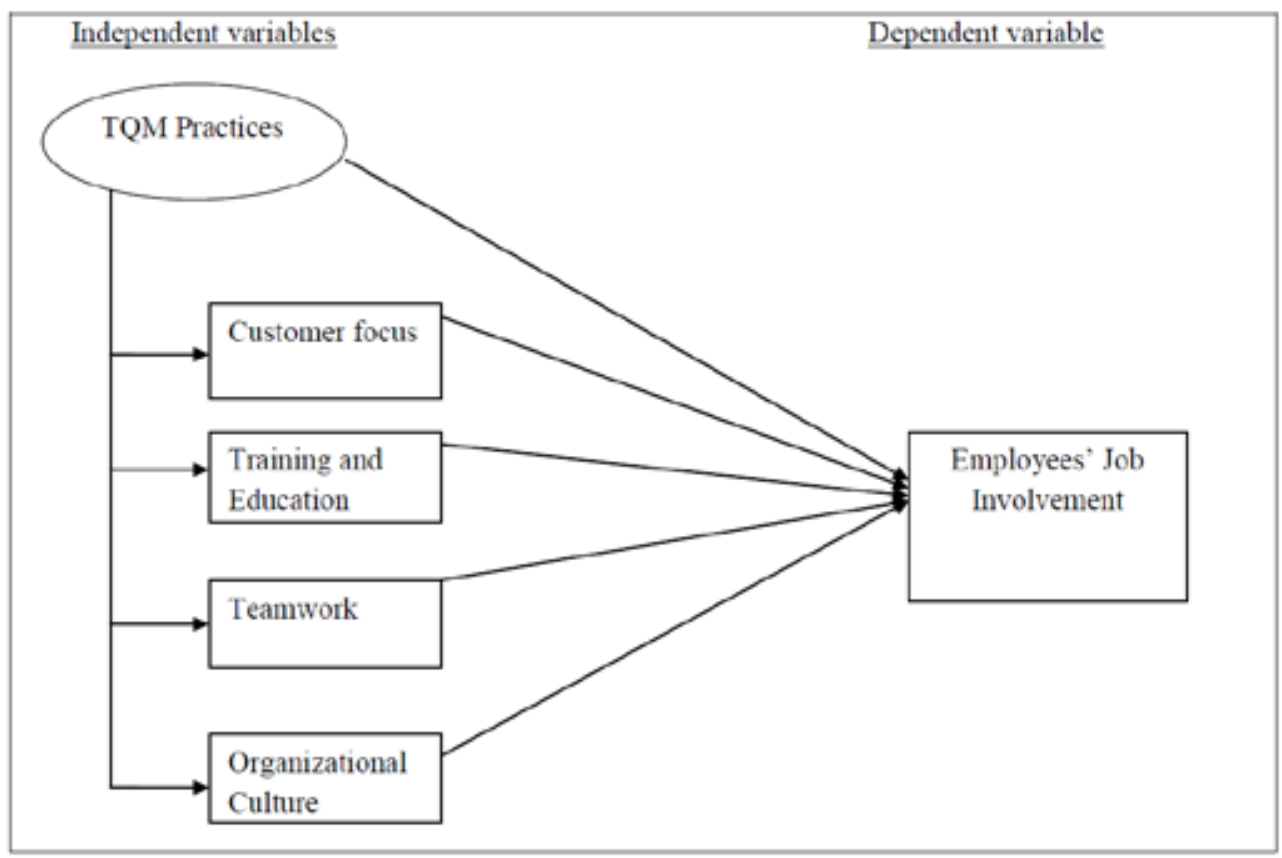




\section{Methodology}

Quantitative approaches have been used to investigate the impact of TQM practices on employees' job involvement in Nepalese manufacturing industry. Descriptive research design has been used to describe nature of variables so as to develop a better understanding of the employees' job involvement, based on TQM practices. Correlational research has been used to determine the relationship between dependent variable (employees' job involvement) and independent variable (TQM practices). Causal- comparative research has been used to demonstrate the variation in the dependent variable that can be explained by the independent variable. All employees of manufacturing industries are considered as population of the study. All managers, senior officials and junior officials of thirteen manufacturing industries are sample. Convenience sampling technique is used to select the industries \& respondents and their offices of selected industries are in Kathamandu and Chitwan district. Primary data have been used. Data collection period is January, 2017 to May, 2017. The structured questionnaires are the main form of data collection. The 450 questionnaires are distributed to all managers, senior officials and junior officials of different job functions within thirteen manufacturing industries. Different job functions are administration, production, marketing, and engineering. Out of 450 questionnaires are distributed to all managers, senior officials and junior official in these industries, 405 questionnaires are returned however, only 384 questionnaires are usable. The total 384 usable questionnaires have been used, yielding a response rate of 90 percent whereas the useable response rate is 85.33 percent.

\section{Instrumentation}

Customer focus and training \& education are measured by a five-item scale and ranges from (1) "strongly disagree" to (5) "strongly agree" developed by Zhang (1999). Teamwork is measured by using four-point Likert scale developed by Flynn et al. (1994) and Lau and Idris (2001). In this study, responses are on five- point Likert scale and ranges from (1) "strongly disagree" to (5) "strongly agree". Organizational culture is measured by a four-point Likert scale adapted from Lau and Idris (2001). In this study, responses are on five- point Likert scale and ranges from (1) "strongly disagree" to (5) "strongly agree. Employees' job involvement is measured by using scale based on Kanungo's (1982) study. In this study, responses measure on a five- point Likert scale ranging from "very low" (1) to "very high" (5).

\section{Techniques of Analysis}

Frequency distribution has been applied to show the respondent's profile. Cronbach's Alpha has been used for reliability test of questions. Mean and standard deviation has been used for descriptive analysis. Correlation analysis has been utilized to identify the relationship between employees' job involvement and TQM practices variables. Simple regression analysis has been operated to show the variance in the employees' job involvement (dependent variable) that can be explained by the TQM practice (independent variable). 


\section{Data Analysis}

\section{Respondent's Profiles}

Data analysis is based on three hundred eighty four respondents in this study. The respondent's profile (personal and demographic information) is presented in table I.

Table I Respondents' Profile

\begin{tabular}{lcc}
\hline & Frequency & Percentage \\
\hline Gender & & \\
Male & 311 & 81.0 \\
Female & 73 & 19.0 \\
Marital Statues & & \\
Single & 96 & 25.0 \\
Married & 288 & 75.0 \\
Age Group (Years) & & \\
Less than25 & 95 & 24.7 \\
25- 34 & 143 & 37.2 \\
35-45 & 134 & 34.9 \\
More than 45 & 12 & 3.1 \\
Educational Level & & 12.0 \\
Intermediate Degree & 46 & 79.7 \\
Diploma Degree & 306 & 8.3 \\
Master Degree & 32 & \\
Administration & & 44.3 \\
Production & 170 & 18.8 \\
Marketing & 72 & 22.1 \\
Engineering & 85 & 14.8 \\
Job Function & 57 & 63.5 \\
Managers & & 31.8 \\
Senior Officials & 244 & \\
Junior Officials & 122 &
\end{tabular}

\section{Reliability Analysis}

The Cronbach's alpha of all variables range from 0.600 to 0.666 . The smallest Cronbach's alpha (0.600) has been in dependent variable of employees' job involvement and the highest Cronbach's alpha (0.666) has been in independent variable of training \& education. The Cronbach's alpha for all variables (dependent and independent) have been above 0.6. According to Nunnally (1967), alpha coefficients are the minimum of 0.6 and above are considerably acceptable. (Table II)

\section{Descriptive Statistics}

The mean score of variables range from 2.855 to 3.368. Customer focus with the highest mean score $(M=3.368)$ is perceived the most dominant TQM practice within their organization. Organizational culture $(\mathrm{M}=3.171)$ which is all rated as moderate 
practices of their organization. Training \& education and teamwork with the lowest mean score $(\mathrm{M}=2.855, \mathrm{M}=2.881)$ are perceived on the overall as least practiced with this organization respectively. The mean scores of employees' job involvement (3.296) is moderate. The mean score of TQM practices $(M=3.068)$ is moderate. The standard deviations range from 0.533 to 0.755 . The standard deviations for independent variables are quite high, indicating that the dispersion are widely spread distribution according to a normal distribution (table II).

\section{Results}

\section{Correlation Analysis}

Correlation analysis is used to determine the relationship between employees' job involvement and TQM practices (customer focus, training and education, teamwork, and organizational culture). If correlation coefficient (r) is from 0.4 to 0.7 , then strength of relationship is moderate and if correlation coefficient ( $r$ ) is from 0.7 to 0.9 , then strength of relationship is strong or high (Rowntree, 1987). Correlation analysis is presented in table II.

Table II

Mean, Standard Deviations, Reliability and Correlations for TQM Practices and Employees' job involvement $(\mathrm{N}=384)$

\begin{tabular}{|c|c|c|c|c|c|c|c|c|c|}
\hline & Mean & $\mathrm{SD}$ & Reliability & $\mathrm{CF}$ & T_E & $\mathrm{T}$ & $\mathrm{OC}$ & EJI & TQM \\
\hline Customer Focus (CF) & 3.368 & 0.694 & 0.655 & 1 & & & & & \\
\hline $\begin{array}{l}\text { Training and } \\
\text { Education (T_E) }\end{array}$ & 2.855 & 0.755 & 0.666 & $.635^{* *}$ & 1 & & & & \\
\hline Teamwork (T) & 2.881 & 0.673 & 0.622 & $.685^{* *}$ & $.571^{* *}$ & 1 & & & \\
\hline $\begin{array}{l}\text { Organizational } \\
\text { Culture (OC) }\end{array}$ & 3.171 & 0.665 & 0.630 & $.789^{* *}$ & $.436^{* *}$ & $.805^{* *}$ & 1 & & \\
\hline $\begin{array}{l}\text { Employees' Job } \\
\text { Involvement (EJI) }\end{array}$ & 3.296 & 0.533 & 0.600 & $.634^{* *}$ & $.516^{* *}$ & $.771^{* *}$ & $.726^{* *}$ & 1 & \\
\hline TQM practices (TQM) & 3.068 & 0.598 & 0.723 & $.903^{* *}$ & $.782^{* *}$ & $.884^{* *}$ & $.871^{* *}$ & $.766^{* *} 1$ & 1 \\
\hline
\end{tabular}

The correlations coefficients of all variables range from 0.516 to 0.903 . There is moderate correlations between customer focus and employees' job involvement $(r=0.634)$. Training \& education are moderate correlations with employees' job involvement $(r=0.516)$. There are positively high correlations among TQM practices with employees' job involvement $(r=0.766)$. There are positively high correlations among teamwork with employees' job involvement $(r=0.771)$. There are positively strong correlation among organizational culture with employees' job involvement $(\mathrm{r}=$ 0.726).

\section{Simple Regression Analysis}

Dependent variables are employees' job involvement and independent variables are TQM practices (customer focus, training \& education, teamwork, and organizational culture). SRA is used to explain the impact of change in TQM practices on employees' job involvement shown in table III. 
Table III

Test of Hypotheses Results

\begin{tabular}{llccccccc}
\hline S.N & \multicolumn{1}{c}{ Hypotheses } & $\mathrm{R}^{2}$ & $\mathrm{~F}$ & \multicolumn{3}{c}{$\begin{array}{c}\text { coefficients } \\
(\alpha)\end{array}$} & $\begin{array}{l}(\beta) \\
\text { P-value }\end{array}$ & Results \\
\hline 1 & $\begin{array}{l}\text { H1 : TQM practices have a positive } \\
\text { effect on employees' job involvement. }\end{array}$ & 0.586 & 541.772 & 9.612 & 0.228 & 0.000 & Accepted \\
2 & $\begin{array}{l}\text { Customer focus has a positive effect on } \\
\text { employees' job involvement. }\end{array}$ & 0.401 & 256.154 & 13.272 & 0.648 & 0.000 & Accepted \\
3 & $\begin{array}{l}\text { Training and education have a positive } \\
\text { effect on employees' job involvement. }\end{array}$ & 0.267 & 138.861 & 18.040 & 0.486 & 0.000 & Accepted \\
4 & $\begin{array}{l}\text { Teamwork has a positive effect on } \\
\text { employees' job involvement. }\end{array}$ & 0.595 & 561.067 & 12.293 & 0.814 & 0.000 & Accepted \\
5 & $\begin{array}{l}\text { Organizational culture has a positive } \\
\text { effect on employees' job involvement. }\end{array}$ & 0.527 & 425.719 & 11.609 & 0.776 & 0.000 & Accepted \\
\hline
\end{tabular}

$\mathrm{R}^{2}$ is 0.586 , which means around 59 percent of total variation in employees' job involvement is explained by TQM practices. Coefficient of TQM practices $(0.228)$ is positively significant $(\mathrm{P}$ - value $=0.000)$. Coefficient of constant $(9.612)$ is also positively significant $(\mathrm{P}$-value $=0.000)$. Thus, TQM practices have a positive effect on employees' job involvement is signified.

Around 40 percent of total variation in employees' job involvement is explained by customer focus $\left(R^{2}=0.401\right)$. Coefficient of customer focus $(0.648)$ is positively significant $(\mathrm{P}$-value $=0.000)$. Coefficient of constant $(13.272)$ is also positively significant $(\mathrm{P}$-value $=0.000)$. Consequently, customer focus has a positive effect on employees' job involvement is accepted.

$\mathrm{R}^{2}$ is 0.267 , which means training and education explains around 27 percent of total variation in employees' job involvement. Coefficient of training and education $(0.486)$ is positively significant $(\mathrm{P}$-value $=0.000)$. Coefficient of constant (18.040) is also positively significant $(\mathrm{P}$-value $=0.000)$. So, training and education have a positive effect on employees' job involvement is verified.

Around 60 percent of total variation in employees' job involvement is explained by teamwork $\left(\mathrm{R}^{2}=0.595\right)$. Coefficient of teamwork $(0.814)$ is positively significant $(\mathrm{P}$-value $=0.000)$. Coefficient of constant (12.293) is also positively significant (P-value $=0.000)$. As a result, teamwork has a positive effect on employees' job involvement is proved.

$\mathrm{R}^{2}$ is 0.527 , which means organizational culture explains around 53 percent of total variation in employees' job involvement. Coefficient of organizational culture $(0.776)$ is positively significant $(\mathrm{P}$-value $=0.000)$. Coefficient of constant $(11.609)$ is also positively significant $(\mathrm{P}$-value $=0.000)$. Therefore, organizational culture has a positive effect on employees' job involvement is verified.

\section{Discussions}

The overall objective of this paper is to investigate the impact of TQM practices on employees' job involvement within thirteen Nepalese manufacturing industry. The result of this study reveals that TQM practices have a positive significant impact on employees' job involvement within thirteen Nepalese manufacturing industry. Basically 
changing the TQM practices, a manager can increase the involvement of employment in the job. This result supports the finding from previous study conducted by Karia and Asaari (2006) found that TQM practices had significant impact on employees' job involvement. This study's result supports the finding from previous study conducted by Ooi et al. (2007a) found that TQM practices were positively associated with employees' job involvement.

The result indicates that Customer focus has a positively significant effect on employees' job involvement. Firms continuously satisfy customer needs and expectations. Customer needs and expectations are associated with job involvement and more favorable perceptions of the work outcome. This study's result supports the finding from previous study conducted by Ooi et al. (2007a) found that customer focus was positively associated with employees' job involvement. However, the result is contrast with the finding of a study by Karia and Asaari (2006), which found that customer focus did not contribute to employees' job involvement. The result is inconsistent with previous research which found that customer focus did not demonstrate any favorable contribution to the employees' job involvement (Batista et al., 2013).

The result of this study specifies that training and education have a positive effect on employees' job involvement. Training and education provide to enhance the employees' skills and knowledge to do the better work and to retain long time. The current study is consistent with previous research, which found that training and education was significantly positive related to job involvement (Ooi et al., 2005). The result of this study is supported by Karia and Assari (2006) found that training and education had a positive effect on employees' job involvement. However, the result is inconsistent with the previous finding of Ooi et al., (2007a) regarding training and education was not a signification predictor of job involvement amongst employees. The result is contrast with the finding of a study by Batista et al. (2013), which found that training and education did not demonstrate any favorable contribution to employees' job involvement.

This study's finding shows that teamwork has a significant positive effect on employees' job involvement. Teamwork is the important TQM practices in enhancing employees' job involvement. Managers must train employees with respect to teamwork. Employees should feel free to control and manage their own work areas. The result of this study is supported by Ooi,et al. (2005) recognized that teamwork had positive effect on job involvement. This result of study supports the finding from previous study conducted by Karia and Assari (2006) found that teamwork had positive effect on job involvement. The current study is consistent with previous research, which found that teamwork was significantly positive related to employees' job involvement (Ooi et al., 2007a). The result is consistent with the finding of a study by Batista et al. (2013) which found that teamwork had a significant and positive correlation with job involvement.

The finding of this study displays that organizational culture has a significant positive effect on employees' job involvement. Organizational culture is able to change, guide, and display behavior of the individual. The result of this study is supported by Ooi, et al. (2005) which found that organizational culture had a significant positive effect on job involvement.

\section{Conclusions}

Customer focus, organizational culture, and employees' job involvement of mean 
score are more than moderate. The variables of training \& education, and teamwork of mean score are below moderate. As a result, almost respondents have given the responses moderately.

TQM practices have a strong relationship with employees' job involvement. Customer focus is a moderate relationship with employees' job involvement. Training and education have a moderate relationship with employees' job involvement. Teamwork and organizational culture has a strong relationship with employees' job involvement. Consequently, this aspect of employees' job involvement is enhanced by TQM practices.

The objective of this paper is that TQM practices impact on employees' job involvement. TQM practices emphasize on empowering people by providing decision making authority to individuals and groups at different levels of organization. TQM practices encourage employees' participation, promote empowerment, recognize that employees play an important role in achieving the organizations' objectives, and treat employees are primary resources. The present study confirms that TQM practices enhance the employees' job involvement.

This study's objective is that customer focus impacts on employees' job involvement. Customer is the most import important part of the production line; product should be aimed at the needs of the customer. Customer focus is the best TQM practices for achieving organizational success. Customer focus indicates that management gives some effort and succeeded to translate its commitment into this improvement practice. This may be supportive relationship between employees and customers. Thus, Customer focus boosts the employees' job involvement.

The objective of this paper is that training and education impact on employees' job involvement. Training and education are essential for continuous improvement in employees' skills. Training and education explore the knowledge to employees. A successful training and education program create more favorable employee attitudes and loyalty, and help employees in their personal development and advancement. Hence, Training and education develop the employees' job involvement.

This study's objective is that teamwork impacts on employees' job involvement. Teamwork provides an atmosphere of mutual relationship, involvement and the participation throughout the organization. Teamwork is a work arrangement that arguably has the capacity to enable cooperation and effective individual involvement. Thus, teamwork improves the employees' job involvement.

The objective of this paper is that organizational culture impacts on employees' job involvement. Organizational culture is considered to be a set of values shared among the employees. Organizational culture provides employees' capabilities and abilities to have control their work, to make changes to the organization. So, organizational culture changes on employees' job involvement.

\section{Implications}

This study provides some insights for managerial level employees for managing human resources in the manufacturing sector of Nepal. This study allows the industries to understand the different dimensions of TQM practices. It presents the relationship between TQM practices and employees' job involvement in Nepalese manufacturing industry. The research results in consistent with previous findings. There are many 
studies that claim the role of TQM practices in improving the overall employees' job involvement of the industry.

The managers in the Nepalese manufacturing sectors should pay attention to the importance of the different dimensions of TQM practices so that different types of TQM practices can be formulated and implemented in their manufacturing sectors. The results suggest that all TQM practices should be considered while formulating TQM polices. But, more emphasis is to be given to customer focus, training and education, teamwork, and organizational culture.

Successfully, implementation of the TQM practices is used in the manufacturing industry to achieve organizational goals and to retain skillful and knowledgeable employee till long period. Further, automatically enhance employees' job involvement. The findings of this research are expected to provide references to managers of Nepalese manufacturing industries. Managers can design effective TQM practices for employees' job involvement.

Regarding practical implications, given the direct influence of certain TQM practices on employees' job involvement, the top management in the organization should conduct formal TQM programs for all new employees and provide their existing employees with continuous formal training and education program (on- the- job as well as off- the- job) in order to gain employees' attitudes and subsequently reduce their turnover rate. This study also contributes by presenting very useful implications and recommendations for Nepalese manufacturing industries to properly implement TQM practices and improve their employees' job involvement.

It is proposed that future research should be conducted in other types of manufacturing industries using a similar approach. It is also important that other major constructs related to the TQM practices should be added to the conceptual framework underlying this study.

\section{References}

Adhikari, D. R. (2008). Principles of Management. Kathmandu: Dhaulagiri Books and Stationery.

Batista, M., Feijo, A., \& Silva, F. (2013). Quality management and employees' attitudes: An example from certified enterprises. Management Research: The Journal of the Iberoamerican Academy of Management, 11(3), 260-279.

Cai, S. (2009). The importance of customer focus for organizational performance: A study of Chinese companies. International Journal of Quality \& Reliability Management, 26(4), 369-379.

Campbell, D. T. (1963). Social attitudes and other acquired behavioral dispositions. New York: McGraw-Hill.

Chapagain, D. P. (2002). Scripting on a Clean Board rather than Deskilling Adult: A Sustainable Approach for TQM Promotion. 7th National Quality Convention, Dhaka, Bangladesh.

Chapagain, D. P. (2010). A quality movement in Nepal. Asia pacific quality organization's 16th international conference on quality.

Cherrington, D. J. (1995). The Management of Human Resources. 4th ed. Englewood Cliff, New Jersey: Prentice-Hall.

Ciampa, D. (1991). The CEO's role in time- based competition. Blackburn, JD (ed.), 273-293.

Fishbein, M. (1967). Readings in attitude theory and measurement. New York: Wiley.

Flynn, B. B., Schroeder, R. G., \& Sakakibara, S. (1994). A framework for quality management research and an associated measurement instrument. Journal of Operations Management, 
11(4), 339-366.

Gallear, D., \& Ghobadian, A. (2004). An empirical investigation of the channels that facilitate a total quality culture. Total Quality Management \& Business Excellence, 15(8), 1043-1067.

Goetsch, D. L., \& Davis, S. M. (1994). Introduction to Total Quality: Quality, Productivity, Competitiveness. New York: Macmillan College Publishing Company.

Guimaraes, T. (1996). TQM's impact on employee attitudes. The TQM Magazine, 8(1), 20-25.

Hemmelgarn, A. L., Glisson, C., \& Dukes, D. (2001). Emergency room culture and the emotional support component of family-centered care. Children's Health Care, 30(2), 93-110.

Igbaria, M., Parasuraman, S., \& Badawy, M. K. (1994). Work experiences, job involvement, and quality of work life among information systems personnel. MIS Quarterly, 18(2), 175-201.

Kanji, G. K., \& Asher, M. (1993). Total quality management process: A systematic approach, advances in total quality management series. London: Carfax publishing Company.

Kanungo, R. N. (1982). Measurement of job and work involvement. Journal of Applied Psychology, 67(3), 341-349.

Karia, N., \& Asaari, A. H. (2006). The effects of total quality management practices on employees' work-related attitudes. The TQM Magazine, 18(1), 30-43.

Kotter, J. P., \& Heskett, J. L. (1992). Corporate Culture and Performance. New York: Free Press.

Lau, H. C., \& Idris, M. A. (2001). The soft foundation of the critical success factors on TQM implementation in Malaysia. The TQM Magazine, 13(1), 51-62.

Lodahl, T. M., \& Kejnar, M. (1965). The definition and measurement of job involvement. Journal of Applied Psychology, 49(1), 24-33.

Luthans, F. (1995). Organizational Behavior. 7th ed. New York: McGraw-Hill.

Nunnally, J. C. (1978). Psychometric Theory. 2nd ed. New York, NY: McGraw-Hill.

Ooi, K. B., Arumugam, V., \& Hwa, T. S. (2005). Does soft TQM predict employees' attitudes?. The TQM Magazine, 17(3), 279-289.

Ooi, K. B., Arumugam, V., Safa, M. S., \& Bakar, N. A. (2007a). HRM and TQM: Association with job involvement. Personnel Review, 36(6), 939-962.

Ooi, K. B., Bakar, N. A., Arumugam, V., Vellapan, L., \& Loke, A. K. Y. (2007b). Does TQM influence employees' job satisfaction? An empirical case analysis. International Journal of Quality \& Reliability Management, 24(1), 62-77.

Pettigrew, A. M. (1979). On studying organizational culture. Administrative Science Quarterly, 24(4), 570-581.

Rowntree, D. (1987). Statistics without Tears. New York, NY: Penguin Book.

Schein, E. H. (1983). Organisational Psychology. 3rd ed. New Delhi, India: Prentice Hall of India Private Limited.

Talib, F., Rahman, Z., \& Qureshi, M. N. (2013). An empirical investigation of relationship between total quality management practices and quality performance in Indian service companies. International Journal of Quality \& Reliability Management, 30(3), 280-318.

Thapa, N. (2015). Total quality management and organizational performance in Nepalese tourism industry: the role of market orientation. Unpublished M. Phil thesis, Faculty of Management M. Phil Programme, Kathmandu.

Thapa, T. B. (2067). Educational Management and Organization Behavior. 2nd ed. Kathmandu: sunlight publication.

Thapa, T.B. (2011). Total Quality Management in Education. Academic Voices A Multidisciplinary Journal, 1(1), 80-83.

Zhang, Z. (2000). Developing a model of quality management methods and evaluating their effects 
Pravaha Journal-2018

on business performance. Total Quality Management, 11(1), 129-137.

Zhang, Z. (1999). Developing an Instrument for Measuring TQM Implementation in a Chinese Context. Groningen: University of Groningen. 